\title{
Chemical and microbial properties of farmer's field soils fertilized with municipal solid wastes without pretreatment in the peri-urban zone of Ouagadougou, Burkina Faso
}

\author{
E. HIEN ${ }^{1,2 *}$, T.W. KABORE ${ }^{1}$, A. BILGO ${ }^{3}$, S.N. SALL ${ }^{4}$ and D. MASSE ${ }^{4}$ \\ ${ }^{1}$ Université de Ouagadougou, UFR/SVT, 03 BP 7021 Ouagadougou 03, Burkina Faso. \\ ${ }^{2}$ Institut de Recherche pour le Développement, UMR Eco\&Sols Centre de Ouagadougou, Burkina Faso. \\ ${ }^{3}$ Institut de l'Environnement et des Recherches Agricoles, Département GRN/SP, O1 BP476 Ouagadougou 01, \\ Burkina Faso. \\ ${ }^{4}$ Institut de Recherche pour le Développement, UMR Eco\&Sols, Centre ISRA-IRD Bel Air Dakar, Sénégal. \\ *Corresponding author, E-mail: edmond.hien@ird.fr;01 BP 6852 Ouagadougou, Burkina Faso. \\ $\mathrm{Tel}+22670263636 . \mathrm{Fax}+(226) 50310385$.
}

\begin{abstract}
Peri-urban agriculture can contribute to food security and nutrition in developing countries. However, due to rising mineral fertilizer prices, farmers in these countries such as Burkina Faso are supplying the required nutrients to their fields by adding municipal solid waste (MSW). This uncontrolled use of waste matter that is not treated could pose several risks on soil quality. The aim of this study was to evaluate the impact on chemical and microbial soil properties of this nasty, but current practice. The study investigated the chemical and microbial characteristic of soils receiving different quantity of waste for several years (20, 10 and 7 years). Soils were sampled around the city of Ouagadougou (Burkina Faso). Soil chemical (C, N, P and pH) and microbial (basal respiration, microbial biomass and microbial diversity) characteristics were assessed. A comparison between unamended soils and the amended ones revealed that the MSW increased soil C, N and P content up to 2 fold. The increase was higher in the 20 years old field that received MSW. The microbial biomass evaluated by the substrate induced respiration method was significantly higher in soils fertilized with MSW, while the microbial activity determined by 21-day soil respiration was not significantly different between treatments. The catabolic diversity was not significantly different. These results suggested that the accumulated organic matter in supplied MSW soils would present particular properties notably a slight biodegradability. This study showed that while the chemical characteristic was related to different quantity of MSW, through different years applied, the microbial activities were not significantly modified. The informal quantity and quality added were discussed.
\end{abstract}

(C) 2010 International Formulae Group. All rights reserved.

Keywords: Urban, agriculture, soil, carbon, nitrogen, SIR, microbial activity.

\section{INTRODUCTION}

There is an explosion of interest among researchers in the development potential of farming in and around Africa's urban areas, or what is now widely referred to as 'urban and peri-urban agriculture' (Drechsel and Kunze, 2001). In sub-saharan African cities, the economic decline will be accompanied by high population growth by 2020 (Drechsel and Kunze, 2001). Urban and peri-urban 
agriculture may have a role to play in addressing urban food insecurity and unemployment problems, which are bound to become increasingly important (Mougeot, 2006). The market opportunity associated with apparent cost-effective way contributed to increase in the importance of urban agriculture as a survival strategy. However, due to rising mineral fertilizer prices it became difficult for farmers of these developing countries to supply the required nutrients to their fields. In addition, urban farming is fast becoming a tangible way of responding to the overwhelming problems of resource scarcity and waste management.

The increasing waste production could be alternatively an important nutrient source for plants (Binder and Patzel, 2001) that can be used to restore the fertility of soils (Furedy et al.. 1999; Pascual et al., 1999). In Burkina Faso, the supply of raw waste material on soils remains a usual practice as it was efficient particularly for cereal production according to farmers (Eaton and Hilhorst, 2003). The waste material could be, at the same time, a cheap supply of nutrients for farming and an alleviation of the waste disposal problem in this country. However, as the solid urban wastes were informally used in field without pre-treatment, it could lead to important environmental risks and soil degradation process (Cointreau, 2006).

Farmers were reported to use a variety of fertilizing materials, including organic residues, papers, poultry (Eaton, 2003). The impact of this specific practice on soil properties is not formally documented in Burkina Faso. Little has been published on the chemical and microbial properties of the implications of uncontrolled use of MSW. The implications in the fields vary depending on the number of years that the farmer uses wastes. Therefore, our objective was to assess the effect of duration in the use of uncontrolled municipal solid waste on soil chemical parameters and microbial activities.
To assess soil chemical, organic matter fractions (total organic carbon, nitrogen and phosphorous) and $\mathrm{pH}$ were measured. Soil microbial parameter was herein investigated by measuring microbial biomass $\mathrm{C}$, basal respiration, $\mathrm{N}$ mineralization and microbial diversity.

The microbial biomass is a reliable indicator of soil quality between different land use systems (Powlson et al., 1987; Insam and Domsch, 1988). Moreover, the ratio of microbial biomass with soil organic carbon was measured to evaluate the response of an ecological system towards a disturbance (Insam and Haselwandter, 1989; Wardle and Ghani, 1995). The diversity of microorganisms is essential to assess soils services as biogeochemical cycles (Nannipieri et al., 2003). Degens and Harris (1997) proposed to measure a catabolic response profile to define a catabolic diversity for a given soil.

\section{MATERIALS AND METHODS \\ Study site}

Ouagadougou is in the north sudanian climatic zone with an annual rainfall average of $694 \mathrm{~mm}$. The monthly temperatures are between $22.7{ }^{\circ} \mathrm{C}$ and $35{ }^{\circ} \mathrm{C}$ (1998 to 2003). Three sites were selected in the peri-urban zone of Ouagadougou: Toudbweogo (TW) $\left(12^{\circ} 25^{\prime} \mathrm{N}\right.$; $\left.01^{\circ} 30^{\prime} \mathrm{W}\right)$, Polosgo (PG) (12 $26^{\circ} \mathrm{N}$; $\left.01^{\circ} 29^{\prime} \mathrm{W}\right)$ and Ourgou (OG) $\left(12^{\circ} 26^{\prime} \mathrm{N}\right.$; $\left.01^{\circ} 32^{\prime} \mathrm{W}\right)$. All soils were referred as petroplinthic leptosol (FAO, 2006).

\section{Farmer's field sample}

After enquiry in each site, fields annually supplied with solid urban wastes (MSW) and adjacent fields with no solid urban wastes supply (control) were identified and sampled; five MSW plots and five control plots in TW and PG and four of each one in OG sites. The use of solid urban wastes as fertilizers by the farmers at the sampling time was more than 20 years old (TW), 10 years old (PG) and 7 years old (OG). The actual 
supplies of solid urban wastes on the sampled farmer's fields were not measured. However, according to a survey on farmers practices, the quantity of solid urban wastes inputs varied from 20 t.ha ${ }^{-1}$ to 50 t.ha $^{-1}$ (Kaboré, 2004). This variability of quantity was explained by the distance between the fields and the town that determined the cost of the transport. Since the TW fields were the closest to the city of Ouagadougou these fields received large quantities of solid urban wastes. The waste spread on soil contained a large range of materials: organic and inorganic. The organic materials concerned vegetables wastes from markets, cooking wastes, ornamental garden residues and other specific organic matters as papers and carton. According to Eaton (2003), the organic matter fraction of the solid wastes from Ouagadougou town accounted for about one-third of the total. The non biodegradable materials (glass, plastics, scrap iron or cans) were sorted out and discarded. However, a lot of these non biodegradable materials remained on soils and it was easy to distinguish the fields that were amended or not with solid urban wastes. All sampled fields were cropped with Sorghum bicolor according to the same tillage practice, without mineral fertilizers addition.

\section{Soil samples}

Soil samples were collected in November and December 2003 during the post harvest period. At this time, solid urban wastes spreading were made between January and May (dry season). In each plot, ten samples were taken at $10 \mathrm{~cm}$ depth every two meters along a $20 \mathrm{~m}$ transect. The samples were air dried, sieved at $2 \mathrm{~mm}$ and stored at room temperature. Samples from the same plot were mixed together to make the composite sample. These composite samples were used for chemical and biological analysis.

\section{Chemical and microbiological soil analysis}

Total soil organic carbon (C) and nitrogen $(\mathrm{N})$ contents were determined by
Walkley and Black (1934) and Kjeldahl (1883) methods respectively. Total soil P was measured by acid extraction. Soil texture (5 fractions) was determined by the micropipette method after digestion of the soil organic matter by $\mathrm{H}_{2} \mathrm{O}_{2}$. Soil reactivity was measured in soil water and $\mathrm{KCl}$ extracts. Soil $\mathrm{pH}$ was measured in 1: 2.5 soil/ $\mathrm{H}_{2} \mathrm{O}$ volume ratio suspensions. All the methods used during the analysis are described in Pansu and Gautheyrou (2003).

To assess the microbial biomass, a $4 \mathrm{~h}$ incubation test at $28{ }^{\circ} \mathrm{C}$ on soil added with glucose or not was realized. According to the works of (Anderson and Domsch 1978), the microbial biomass was linearly linked to the difference of the $\mathrm{CO}_{2}$ released amount between the soil incubated with glucose and the soil without glucose. Microbial activity was evaluated by the measure of $\mathrm{CO}_{2}$ released and soil mineral nitrogen content during a soil incubation. Briefly, $300 \mathrm{~g}$ of soil was moistened at a humidity of $75 \%$ of the waterholding capacity (12 mL for $100 \mathrm{~g}$ of soil), shared out into fifteen vials placed in a sealed vessel (1 l) for 21 days at $28{ }^{\circ} \mathrm{C}$. $\mathrm{CO}_{2}$ concentration in vessel was measured by a gas analyser (Polytron IR CO2, Dräger@) every day during the 7 first days, then after every two days. After each $\mathrm{CO}_{2}$ determination, the headspaces were flushed with fresh air. Soil water contents were controlled regularly by weighing and were corrected, if necessary, by adding distilled water. Three replicates were done for each sample. At the $1 \mathrm{st}, 3 \mathrm{rd}, 7 \mathrm{th}, 14^{\text {th }}$ and 21 st day of incubation, three vials holding $20 \mathrm{~g}$ of incubated soil were step out from the 1 1 vessel. For $\mathrm{N}$ mineral determination, $20 \mathrm{ml}$ of $1 \mathrm{M} \mathrm{KCl}$ solution were added to $2 \mathrm{~g}$ aliquot of incubated soil. After 1 hour agitation followed by filtration, $\mathrm{NO}_{3}{ }^{-}$and $\mathrm{NH}_{4}{ }^{+}$contents were assessed in the filtrate by automatic colorimeter. The nitrogen mineralization was assessed only on soils sampled in the TW and PG sites.

Microbial functional diversity in soil treatments was assessed by measurement of 
the catabolic respiratory profiles of microbial communities (Degens and Harris, 1997). Thirty-three substrates, including a range of amino acids, carbohydrates, organic acids and amides were screened for differences in SIR responsiveness between soil samples. Substrates were dissolved in $2 \mathrm{ml}$ sterile distilled water and added to $1 \mathrm{~g}$ equivalent dry weight soil in $10 \mathrm{ml}$ bottles. After substrate addition to soil samples, bottles were immediately closed and kept at $28{ }^{\circ} \mathrm{C} . \mathrm{CO}_{2}$ fluxes ( $4 \mathrm{~h}$ ) from soils were assessed using an infrared gas analyser (IRGA) (Polytron IR $\mathrm{CO}_{2}$, Dräger(C).

\section{Statistical analysis}

ANOVA were performed to test the mean equality hypothesis between MSW factor (soils with or without solid urban wastes supplies). Site and interaction (MSW x site) factors were also considered in this analysis. The catabolic diversity was evaluated by the richness and evenness indexes according to Degens and Harris (1997). The richness was the number of metabolised substrates by soil microbial community. The evenness was the variability in substrate use. The catabolic evenness (E) was calculated as $E=1 / \Sigma \mathrm{p}_{\mathrm{i}}{ }^{2}$ where $\mathrm{p}_{\mathrm{i}}$ is summed for all substrates and $p_{i}=r_{i} / \Sigma r_{i}\left[r_{i}\right.$ is the response of each substrate as a proportion of total respiration responses summed over all substrates $\left.\left(\Sigma r_{i}\right)\right]$. All analysis were performed with XLSTAT $\left(\right.$ ADDINSOFT $\left.^{\odot}\right)$.

\section{RESULTS}

Soil organic carbon content, as soil total nitrogen content, was significantly higher in the amended soils with MSW than those of the no amended ones (Table 1). This positive effect of the urban waste was variable according to the site studied. SOC increased by $83 \%, 34 \%$ and $18 \%$ on TW, PG and OG sites respectively. The total soil nitrogen content increment was $53 \%, 39 \%$ and $22 \%$ for sites TW, PG and OG respectively. The waste spreading did not affect soils C:N ratio (Table 1). No significant difference was observed between soils of the MSW and control plots for total phosphorus content. The $\mathrm{pH}$-water and $\mathrm{pH}-\mathrm{KCl}$ were significantly higher on amended soils compared to the control plots (Table 1). On all the sites, $\mathrm{pH}$ was higher on soils amended with wastes.

The substrate induced respiration was significantly higher $(+38 \%)$ in the soils with MSW compared to the control soils (Table 2). The cumulative $\mathrm{CO}_{2}$ released after 21 days of soil incubation (21d released $\mathrm{CO}_{2}$ ) was not significantly different between MSW and control soils for all sites. The 21d released $\mathrm{CO}_{2}$ : Carbon ratio was significantly higher in the control soils (Table 2). At the incubation onset, soil nitrate content and total mineral nitrogen was significantly higher $(\mathrm{p}<0.001)$ in MSW plots (Figure 1). No difference occurred between MSW and control soils for soil ammonium content. During incubation (21 days), nitrates content in soil increased (Figure 1) while ammonium content trended to decrease. After 21 days of incubation, incubated soils showed mineral nitrogen net increase $\left(\mathrm{N}-\mathrm{NH}_{4}{ }^{+}+\mathrm{N}-\mathrm{NO}_{3}{ }^{-}\right)$whatever soil treatments (MSW or control). However, net nitrate production and net $\mathrm{N}$ mineralization from day 0 to day 21 did not differ significantly between MSW soils and the control (Figure 2). Catabolic diversity (Table 3) estimated by richness index was not significantly different $(\mathrm{p}=0.341)$ between MSW amended soils $(27 \pm 1)$ or not $(27.9 \pm$ 1.4). For evenness index, no difference was also noticed ( $14.07 \pm 0.61$ for soil + MSW and $13.04 \pm 1.26$ for soil only). Except for malic and formic acids, catabolic responses to the carboxylic acids were significantly higher in MSW soils than those which were measured on control soils (Figure 3). Significant differences were also observed for three amino acids: serine, glucosamine and glutamic acid. 
Table 1: Chemical properties (mean \pm standard error) of soils from farmers fields with MSW (+MSW) or not (control) in three sites in peri-urban area of Ouagadougou, Burkina Faso.

\begin{tabular}{|c|c|c|c|c|c|c|c|c|c|c|c|c|c|}
\hline \multirow[t]{2}{*}{ Site } & \multirow{2}{*}{$\begin{array}{l}\text { MSW } \\
\text { inputs }\end{array}$} & \multicolumn{2}{|c|}{$\begin{array}{l}\text { Carbon } \\
\left(\mathrm{mg.g}^{-1}\right)\end{array}$} & \multicolumn{2}{|c|}{$\begin{array}{l}\text { Nitrogen } \\
\left(\mathrm{mg.g}^{-1}\right)\end{array}$} & \multicolumn{2}{|c|}{$\mathrm{C} / \mathrm{N}$ ratio } & \multicolumn{2}{|c|}{$\begin{array}{c}\text { Phosphorus } \\
\left(\mu \mathrm{g} . \mathrm{g}^{-1}\right)\end{array}$} & \multicolumn{2}{|c|}{$\mathrm{pH} \mathrm{H_{2 } \mathrm { O }}$} & \multicolumn{2}{|c|}{ pH KCl } \\
\hline & & mean & SE & mean & SE & mean & SE & mean & $\mathbf{S E}$ & mean & SE & mean & SE \\
\hline \multirow[t]{2}{*}{ TW } & $+\mathrm{MSW}$ & 8.10 & \pm 0.67 & 0.55 & \pm 0.05 & 14.9 & \pm 0.6 & 293 & \pm 64 & 7.31 & \pm 0.26 & 6.71 & \pm 0.28 \\
\hline & Control & 4.42 & \pm 0.40 & 0.26 & \pm 0.02 & 17.2 & \pm 1.3 & 134 & \pm 14 & 6.59 & \pm 0.21 & 5.70 & \pm 0.26 \\
\hline \multirow[t]{2}{*}{ PG } & $+\mathrm{MSW}$ & 9.22 & \pm 1.38 & 0.49 & \pm 0.06 & 19.0 & \pm 2.0 & 248 & \pm 36 & 7.51 & \pm 0.02 & 6.99 & \pm 0.05 \\
\hline & Control & 5.92 & \pm 0.60 & 0.30 & \pm 0.05 & 21.8 & \pm 4.3 & 197 & \pm 22 & 6.59 & \pm 0.32 & 5.82 & \pm 0.34 \\
\hline \multirow[t]{2}{*}{ OG } & $+\mathrm{MSW}$ & 5.20 & \pm 0.73 & 0.37 & \pm 0.05 & 14.2 & \pm 1.0 & 183 & \pm 33 & 6.90 & \pm 0.25 & 6.19 & \pm 0.25 \\
\hline & Control & 4.25 & \pm 0.29 & 0.29 & \pm 0.03 & 14.7 & \pm 0.5 & 204 & \pm 30 & 6.10 & \pm 0.09 & 5.04 & \pm 0.12 \\
\hline \multicolumn{14}{|c|}{ ANOVA } \\
\hline \multicolumn{2}{|c|}{ Site effect } & 0.009 & & 0.286 & & 0.042 & & 0.758 & & 0.064 & & 0.017 & \\
\hline \multicolumn{2}{|c|}{$\begin{array}{l}\text { MSW effect } \\
\text { Interaction }\end{array}$} & 0.001 & & $<0.001$ & & 0.317 & & 0.060 & & $<0.001$ & & $<0.001$ & \\
\hline \multicolumn{2}{|c|}{ Site $\times M S W$} & 0.234 & & 0.11 & & 0.868 & & 0.089 & & 0.902 & & 0.936 & \\
\hline
\end{tabular}

Table 2: Microbial properties (mean \pm standard error) of soils from farmers fields with MSW (+MSW) or not (control) in three sites in peri-urban area of Ouagadougou, Burkina Faso.

\begin{tabular}{|c|c|c|c|c|c|c|c|}
\hline \multirow[t]{2}{*}{ Site } & \multirow[t]{2}{*}{ MSW inputs } & \multicolumn{2}{|c|}{$\begin{array}{c}21 \mathrm{~d}-\mathrm{CO}^{\dagger} \\
\left(\mu \mathrm{gC}-\mathrm{CO}_{2} \mathrm{~g}^{-1}\right)\end{array}$} & \multicolumn{2}{|c|}{ 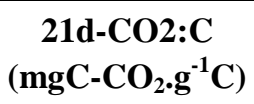 } & \multicolumn{2}{|c|}{$\begin{array}{c}\operatorname{SIR}^{\dagger \dagger} \\
\left(\mu \mathrm{gC}-\mathrm{CO}_{2} \cdot \mathrm{g}^{-1} \cdot \mathrm{h}^{-1}\right)\end{array}$} \\
\hline & & mean & $\mathrm{se}$ & mean & $\mathrm{se}$ & mean & $\mathrm{se}$ \\
\hline \multirow{2}{*}{ TW } & $+\mathrm{MSW}$ & 103 & 14 & 13.2 & 2.2 & 0.89 & 0.23 \\
\hline & Control & 97 & 7 & 23.2 & 3.7 & 0.43 & 0.14 \\
\hline \multirow[t]{2}{*}{ PG } & $+\mathrm{MSW}$ & 124 & 9 & 14.5 & 2.2 & 0.72 & 0.07 \\
\hline & Control & 114 & 7 & 20.1 & 2.6 & 0.56 & 0.17 \\
\hline \multirow[t]{2}{*}{ OG } & $+\mathrm{MSW}$ & 99 & 8 & 20.9 & 5.0 & 0.89 & 0.22 \\
\hline & Control & 95 & 14 & 20.6 & 2.3 & 0.57 & 0.18 \\
\hline
\end{tabular}

Anova

\begin{tabular}{llll} 
Site effect & 0.051 & 0.397 & 0.923 \\
MSW effect & 0.322 & 0.024 & 0.040 \\
Interaction SitexMSW & 0.972 & 0.293 & 0.640 \\
\hline
\end{tabular}

$\dagger$ Released $\mathrm{CO} 2$ during a $21 \mathrm{~d}$ soil incubation; $\dagger \dagger$ Substrate induced respiration ANOVA : probability of the null hypothesis of equality of the mean.

Toudbweogo (TW), Polosgo (PG), Ourgou (OG). 
Table 3: Diversity indices (mean \pm standard error) of the catabolic responses of MSW and control soils to 33 simple organic matters added.

\begin{tabular}{llcc}
\hline Site & MSW inputs & Richness & Evenness \\
\hline TW & + MSW & $29 \pm 1$ & $14.13 \pm 1.15$ \\
& Control & $26 \pm 2.4$ & $10.46 \pm 0.70$ \\
PG & + MSW & $29.4 \pm 2.6$ & $12.71 \pm 0.34$ \\
& Control & $26.6 \pm 2.6$ & $11.12 \pm 2.06$ \\
OG & + MSW & $31 \pm 0.7$ & $15.69 \pm 1.27$ \\
& Control & $32 \pm 0$ & $18.68 \pm 1.13$ \\
ANOVA & & & \\
Site effect & & 0.137 & 0.001 \\
MSW effect & & 0.341 & 0.463 \\
Interaction effect SitexMSW & 0.568 & 0.047 \\
\hline
\end{tabular}

ANOVA : probability of the null hypothesis of equality of the mean. Toudbweogo (TW), Polosgo (PG), Ourgou (OG).
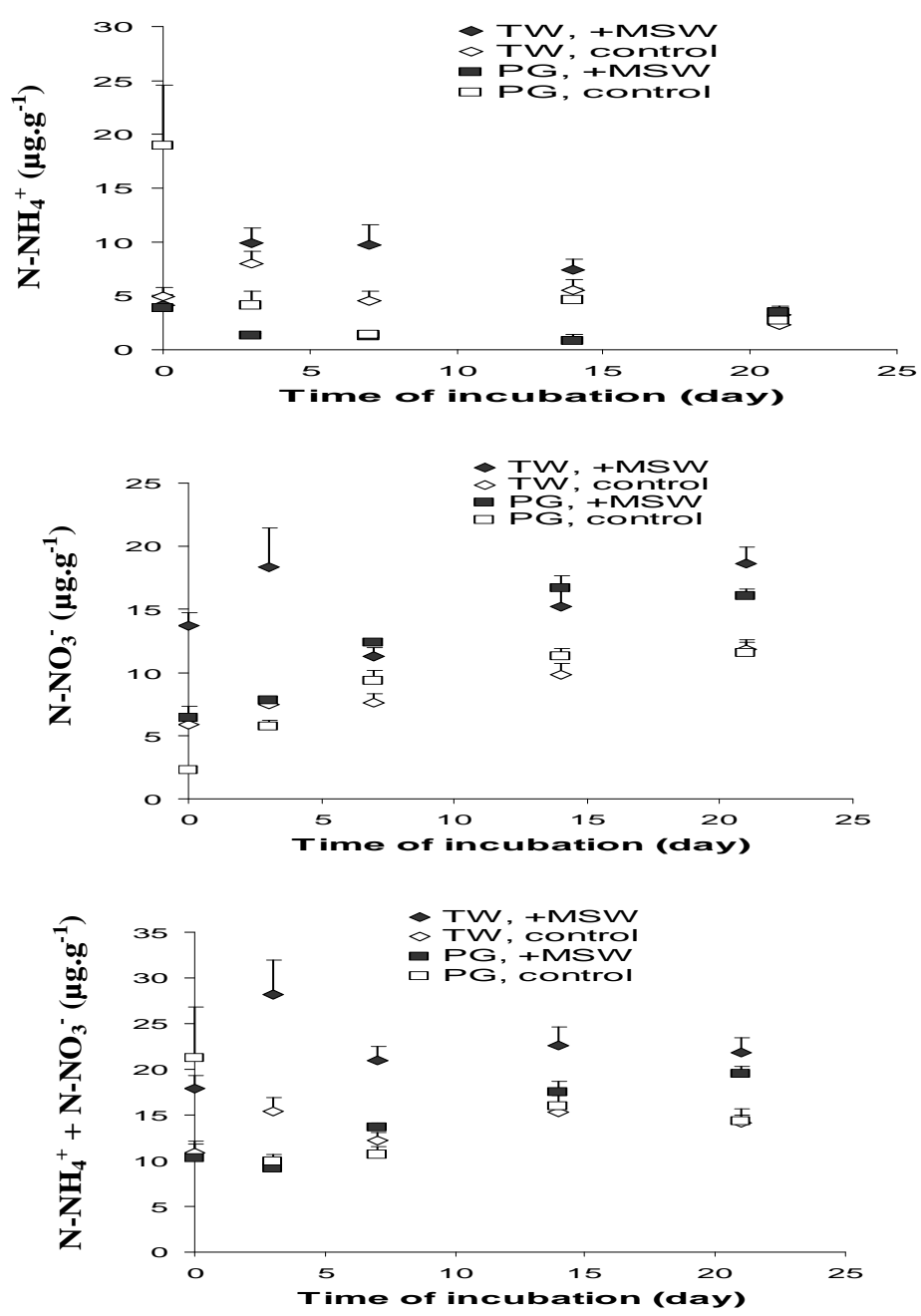

Figure 1: Soil mineral nitrogen $\left(\mathrm{NO}_{3}{ }^{-}\right.$and $\left.\mathrm{NH}_{4}{ }^{+}\right)$contents at different time of incubation of soils from farmers fields with MSW (+MSW) or not (control) in three sites in peri-urban area of Ouagadougou, Burkina Faso. The error bars represent the standard errors. 

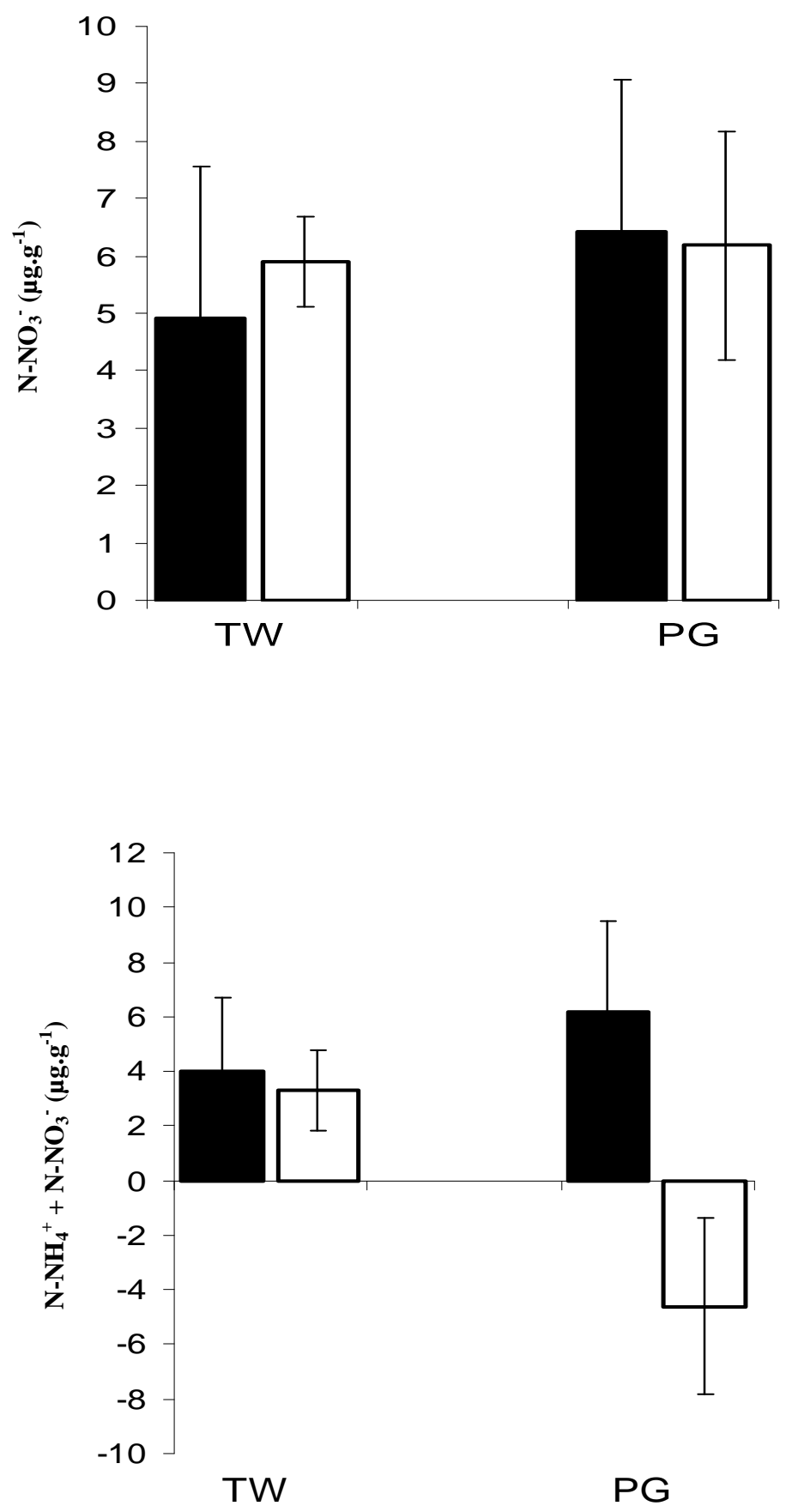

Figure 2: Nitrate and mineral nitrogen balance from 0 to 21 days of incubation of soils from farmers fields with MSW (black) or not (white) in three sites in peri-urban area of Ouagadougou, Burkina Faso. The error bars represent the standard errors.

Toudbweogo (TW), Polosgo (PG), Ourgou (OG). 


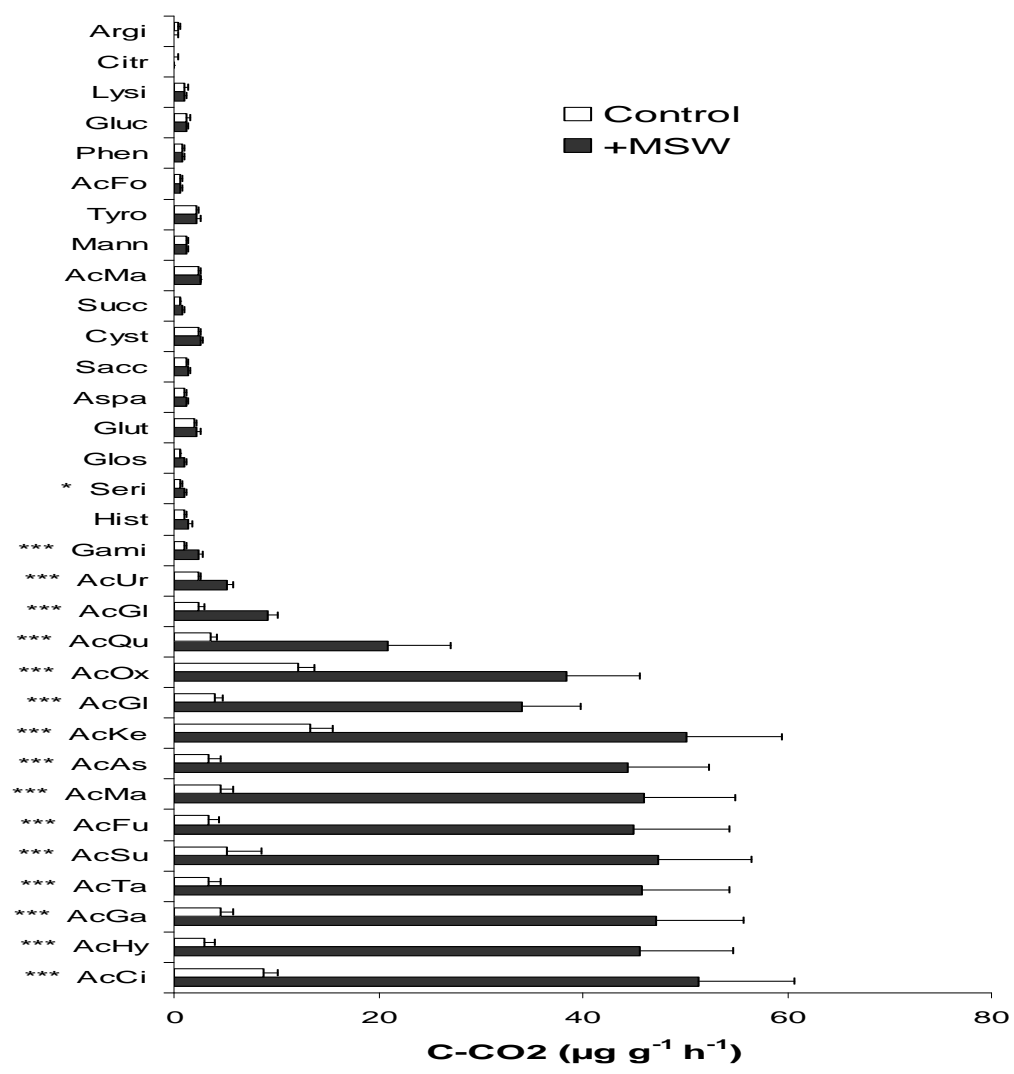

Figure 3: Catabolic responses of MSW amended soils (black bar) and no MSW amended soils (white bar).

*** probability of the null hypothesis of mean equality between soils with MSW and control.

Amino acids : L-serine, seri; Glutamic acid, AcGl; D-Glucosamine, Gami; L-Arginine, Argi; Asparagine, Aspa; L-Cysteine, Cyst; L-Histidine, Hist; L-Lysine, Lysi; L-Phenylalanine, Phen; L-tyrosine, Tyro. Carboxylic acids: Ascorbic acid, AcAs; Citric acid,, AcCi; Fumaric acid, AcFu; Gallic acid, AcGa; Gluconic acid, AcGl; Hydroxybutiric acid, AcHy; Ketoglutaric acid, AcKe; Malonic acid, AcMa; Oxalic acid, AcOx; Quinic acid, AcQu; Succinic acid, AcSu; Tartaric acid, AcTa; Uric acid AcUr, Formic acid AcFo, Malic acid AcMa; Amides : Citrate Citr, Glucamine Gluc, Glutamine Glut, Succinamide Succ. Carbohydrates: Glucose, Glos; Mannose, Mann; Saccharose, Sacc.

\section{DISCUSSION}

\section{Soil chemical properties}

Solid urban wastes in developing countries were particularly rich in biodegradable matter (Cointreau, 2006). According to the studies of waste management in Ouagadougou (Eaton, 2003), the average contents of nitrogen, phosphorus and organic carbon on solid urban wastes were respectively of $0.29 \%, 0.16 \%$ and $5 \%$ of organic carbon. With a range of inputs

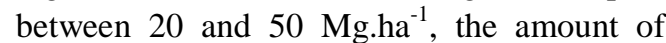
carbon, nitrogen and phosphorus input on the study fields could be estimated respectively around 58 to $145 \mathrm{~kg} \cdot \mathrm{ha}^{-1}$ of nitrogen, 38 to 80 kg.ha ${ }^{-1}$ of phosphorus, and 1 to $2.5 \mathrm{Mg} \cdot \mathrm{ha}^{-1}$ of carbon. These potential nutrients supply could cover the needs for a sorghum grain yield at 2 $\mathrm{Mg} \cdot \mathrm{ha}^{-1}$ which was a significant production in the pedo-climatic context of Burkina Faso (Stoorvogel and Smaling, 1990).

The large increase of soil organic carbon could be attributed to the addition of urban wastes to fertilize soils. Similar results were reported in European countries (Garcia et al., 1994; Pascual et al., 1999). However, these increases in SOM remain lower than those obtained in long term municipal waste 
disposal soils in Nigeria (700\%) (Anikwe and Nwobodo, 2002). In long term experiments of cropping systems in similar soils $(80 \mathrm{~km}$ from Ouagadougou), the maximum SOC contents $\left(0-10 \mathrm{~cm}\right.$ depth) was $7.2 \mathrm{mg} \cdot \mathrm{g}^{-1}$, that was measured on plots which received 10 to 12 $\mathrm{MgC} \cdot \mathrm{ha}^{-1} \mathrm{y}^{-1}$ of manure for 42 years (Hien, 2004; Mando et al., 2005). Although we have not measured the actual amount of wastes supplied on the sampled fields, the maximum carbon input by the solid urban wastes inputs could be estimated at $2.5 \mathrm{MgC} \cdot \mathrm{ha}^{-1} \cdot \mathrm{y}^{-1}$ according to the different studies on wastes management in Ouagadougou (Eaton, 2003). Despite this relative lower amount of carbon supply, the soil carbon content measured on peri-urban soils was equivalent to the carbon content measured on the high manure inputs plots of the long term experiments. One explanation would be that the organic carbon incorporated by the urban wastes was slightly biodegradable that contributed to the storage of carbon on the topsoil of MSW plots.

The results of $\mathrm{N}$ mineralization were recorded as an increase in the concentration of N-NO3- and decrease in NH4+. This might be due to slight alkaline $\mathrm{pH}$ and dissolved oxygen, released as a result of $\mathrm{CaO}_{2}$ degradation that favored the high activity of nitrifying bacteria, which resulted in the formation of nitrate (Sinha and Annchhatre, 2007). The increase of the soil $\mathrm{pH}$ is in accordance with the result. Consequently, the MSW plots could play the role of liming because of its capacity to supply high quantities of $\mathrm{Ca}, \mathrm{Mg}$ and $\mathrm{K}$ (Pasquini and Alexander, 2004).

PG control contained the higher $\mathrm{C} / \mathrm{N}$ ratio (21.8). The direction of $\mathrm{N}$ immobilisation or -mineralization appears to be dependent not only on the rate of supply of $\mathrm{C}$, but also the elemental ratio of supply in relation to optimized microbial needs for cell growth and maintenance. From this perspective, some works reported as a cell physiological response to a shortage of available $\mathrm{C}$ relative to $\mathrm{N}$, reflected in the low $\mathrm{C} / \mathrm{N}$ ratio $(<14)$. The net- $\mathrm{N}$-immobilisation appears to be an inherent physiological response to higher initial $\mathrm{C} / \mathrm{N}$ ratios (>19) of soil. The threshold of $\mathrm{N}$ limitation was discussed by several authors (Recous et al., 1995; Nicolardot et al., 2001; Qiu et al., 2008).

\section{Soil microbial properties}

The difference of $\mathrm{CO} 2$ released during $4 \mathrm{~h}$ between an incubated soil with and without added glucose could be use as an indicator of the microbial biomass (Anderson and Domsch, 1978). The comparison of this indicator would indicate that the microbial biomass was significantly higher $(+38 \%)$ in MSW plots compared to the control plots.

The soil respiration to organic carbon ratio, as the net $\mathrm{N}$ mineralisation, are related to the amount of available organic carbon for microbial activity (Nannipieri et al., 1990; Gabrielle et al., 2004). No difference of these microbial activity indexes between the MSW and control plots indicated that the organic matter accumulated in these soils would be hardly biodegradable. To assess this statement, it would be relevant to measure the proportion of non organic carbon in the soil (Lorenz et al., 2006).

In the present study, despite a higher potential microbial biomass in MSW soils, the $\mathrm{CO}_{2}$ released during the 21days incubation of these soils was not different from the control soils. This indicated that the microbial biomass of the MSW soils would be characterized by a lower requirement in energy of maintenance (Anderson and Domsch, 1990), and a lower microbial efficiency in organic resources used (Wardle and Ghani, 1995).

The microbial community in the soils with or without solid urban wastes addition have globally all the catabolic functions for immediately degrading all tested substrates. It was expected that microbial catabolic diversity increased with the amount of soil organic matter accumulate by MSW soils at the sampling date (Degens et al., 2000; Nsabimana et al., 2004). In our case, the no difference of the catabolic diversity between MSW soils and the control soils. This could 
be relative to the quality of the soil organic matter accumulated with the solid urban wastes inputs practices. If the organic matter was not readily biodegradable, consequently the microbial diversity could not be radically changed. However, MSW soils presented a higher catabolic response in presence of carboxylic acids substrates. As it was reported by Degens (1999), change in catabolic response profiles might be attributable as much to changes in soils properties that influenced the functional state of organisms as to changes in species composition. The municipal solid wastes inputs modified the environmental conditions as the soil organic matter quality or the decrease of soil acidity that could emphasize the activity of some soils microorganisms.

\section{Conclusion}

The chemical analysis of soils fertilized with untreated solid urban wastes showed a high accumulation of soil organic matter. However, according to relative low carbon input by the wastes supplies, and to the analysis of the microbial activity, this organic matter would present particular properties notably a slight biodegradability. The biochemical properties of the organic matter contained in solid urban wastes have to be characterised to specify their link to the microbial diversity structure and functioning of the amended soils. Outside the ecotoxicological aspects that have to be assessed, the future works concern the improvement of the solid urban wastes recycling in agriculture to fulfil both the increasing food demand and the urban wastes management in African countries.

\section{REFERENCES}

Anderson JPE, Domsch KH. 1978. A physiological method for the quantitative measurement of microbial biomass in soils. Soil Biology and Biochemistry, 10: 215-221.

Anderson T-H, Domsch KH. 1990. Application of eco-physiological quotients (qCO2 and $\mathrm{qD}$ ) on microbial biomasses from soils of different cropping histories. Soil Biology and Biochemistry, 22: 251-255.

Anikwe MAN, Nwobodo KCA. 2002. Long term effect of municipal waste disposal on soil properties and productivity of sites used for urban agriculture in Abakaliki, Nigeria. Bioresource Technology, 83: 241-250.

Binder C, Patzel N. 2001. Preserving tropical soil organic matter at watershed level. A possible contribution of urban organic wastes. Nutrient Cycling in Agroecosystems, 61: 171-181.

Cointreau S. 2006. Occupational and environmental health issues of solid waste management. Special emphasis on middle- and lower-income countries. The World Bank Group, Washington, DC.

Degens BP. 1999. Catabolic response profiles differ between microorganisms grown in soils. Soil Biology and Biochemistry, 31: 475-477.

Degens BP, Schipper LA, Sparling GP, Vojvodic-Vukovic M. 2000. Decreases in organic $\mathrm{C}$ reserves in soils can reduce the catabolic diversity of soil microbial communities. Soil Biology and Biochemistry, 32: 189-196.

Drechsel P, Kunze D. 2001. Waste Composting for Urban and Peri-urban Agriculture: Closing the Rural-urban Nutrient Cycle in Sub-Saharan Africa. IWMI, FAO, CABI Publishing: Wallingford, UK.

Eaton D. 2003. Potential for Development of Urban and Peri-Urban Agriculture in Relation to Urban Waste Management in West Africa (APUGEDU). Final Report Recycling Urban Waste in Agriculture. Agricultural Economics Research Institute (LEI), Wageningen.

Eaton D, Hilhorst T. 2003. Opportunities for managing solid waste flows in the periurban interface of Bamako and Ouagadougou. Environment and Urbanization, 15: 53-63.

FAO-IUSS-ISRIC, 2006. World reference base for soil resources. A framework for 
international classification, correlation and communication. World Soil Resources Reports 103. Rome, Italy.

Furedy C, Maclaren V, Whitney J. 1999. Reuse of waste for food production in Asian cities: health and economic perspectives. In For Hunger-Proof Cities. Sustainable Urban Food Systems, KocR M, MacRae LJA, Mougeot, Welsh J (eds). IDRC: Ottawa; 144-154.

Gabrielle B, Da-Silveira J, Houot S, Francou C. 2004. Simulating Urban Waste Compost Effects on Carbon and Nitrogen Dynamics Using a Biochemical Index. Journal of Environmental Quality, 33: 2333-2342.

Garcia C, Hernandez T, Costa F, Ceccanti B. 1994. Biochemical parameters in soils regenerated by the addition of organic wastes. Waste Management and Research, 12: 457-466.

Hien E. 2004. Dynamique du carbone dans un acrisol ferrique du Centre Ouest Burkina: Influence des pratiques culturales sur le stock et la qualité de la matière organique. PhD Thesis Ecole Nationale Supérieure Agronomique de Montpellier, France.

Insam H, Domsch KH. 1988. Relationship between soil organic carbon and microbial biomass on chronosequences of reclaimed sites. Microbial Ecology, 15: 177-188.

Insam H, Haselwandter K. 1989. Metabolic quotient of the soil microflora in relationto plant succession. Oecologia, 79: 174-178.

Kaboré W-TT. 2004. Impacts de l'apport des déchets urbains solides non triés sur les potentialités agronomiques des sols : cas de l'agriculture péri-urbaine de Ouagadougou. IDR.

Kjeldahl J. 1883. Neue methode zur bestimmung des stickstoffs in organischen körpern. Z. Anal. Chem., 22: 366-382.

Lorenz K, Preston CM, Kandeler E. 2006. Soil organic matter in urban soils: Estimation of elemental carbon by thermal oxidation and characterization of organic matter by solid-state 13C nuclear magnetic resonance (NMR) spectroscopy. Geoderma, 130: 312-323.

Mando A, Ouattara B, Somado AE, Wopereis MCS, Stroosnijder L, Breman H. 2005. Long-term effects of fallow, tillage and manure application on soil organic matter and nitrogen fractions and on sorghum yield under Sudano-Sahelian conditions. Soil Use and Management, 21: 25-31.

Mougeot LJA. 2006. Growing better cities. Urban agriculture for sustainable development. IDRC, Ottawa.

Nannipieri P, Grego S, Ceccanti B. 1990. Ecological significance of the biological activity in soil. In Soil Biochemistry, Bollag J-M, Stotzky G (eds). Marcel Dekker, Inc: New-York and Basel; 293355.

Nannipieri P, Ascher J, Ceccherini MT, Landi L, Pietramellara G, Renella G. 2003. Microbial diversity and soil functions. European Journal of Soil Science, 54: 655-670.

Nsabimana D, Haynes RJ, Wallis FM. 2004. Size, activity and catabolic diversity of the soil microbial biomass as affected by land use. Applied Soil Ecology, 26: 81-92.

Pansu M, Gautheyrou J. 2003. L'Analyse du Sol-minéralogique, Organique et Minérale. Springer: Paris, Heildeberg, New York, Honk Kong, Londres, Milan, Tokyo.

Pascual JA García C, Hernandez T. 1999. Lasting microbiological and biochemical effects of the addition of municipal solid waste to an arid soil. Biology and Fertility of Soils, 30: 1-6.

Pasquini MW, Alexander MJ. 2004. Chemical properties of urban waste ash produced by open burning on the Jos Plateau: implications for agriculture. Science of the Total Environment, 319: 225-240.

Powlson DS, Prookes PC, Christensen BT. 1987. Measurement of soil microbial biomass provides an early indication of changes in total soil organic matter due to 
straw incorporation. Soil Biology and Biochemistry, 19: 159-164.

Qiu S, McComb AJ, Bell RW. 2008. Ratios of $\mathrm{C}, \mathrm{N}$ and $\mathrm{P}$ in soil water direct microbial immobilisation-mineralisation and $\mathrm{N}$ availability in nutrient amended sandy soils in southwestern Australia. Agriculture, Ecosystems and Environment, 127: 93-99.

Recous S, Robin D, Darwis D, Mary B. 1995. Soil inorganic $\mathrm{N}$ availability: effect on maize residue decomposition. Soil Biol Biochem, 27: 1529-1538.

Sinha B., Annchhatre AP. 2007. Partial nitrification-operational parameters and microorganisms involved. Rev. Environ. Sci. Biotechnol., 6: 285-313.
Stoorvogel JJ, Smaling EMA. 1990. Assessment of soil nutrient depletion in sub-Saharan Africa: 1983-2000. Report 28. Winand Staring Centre, Wageningen, The Netherlands.

Walkley A, Black A. 1934. An examination of the Degtjareff method for determining soil organic matter and a proposed modification of the chromic acid titration method. Soil Sci., 37: 29-38.

Wardle DA, Ghani A. 1995. A critique of the microbial metabolic quotient $(\mathrm{qCO} 2)$ as a bioindicator of disturbance and ecosystem development. Soil Biology and Biochemistry, 27: 1601-1610. 